\title{
Why Regulate a Privatised Firm?
}

\begin{abstract}
A. R. KEMAL
The paper examines changes in the levels of efficiency as a result of privatisation in Pakistan. By comparing the growth rates of the privatised industries in pre- and postPrivatisation period, changes in relative prices and the rate of return on equity, it concludes that producers may have indulged in monopolistic exploitation. The paper argues that even if the private firms have lower cost curves as compared to public sector at all the levels of output, at the equilibrium, public-sector firms may have lower cost. Accordingly, the regulation of the private monopoly, especially in the non-traded sector, is absolutely necessary. However, if regulation implies uncertainty and less flexibility to private sector firms, even compared with public sector enterprises, then regulated privatesector firms would be counter-productive. It suggests that the perfect contest-ability model which allows the firm to make sufficient profits and leave them free to take the decisions will be a better alternative. The price caps in line with changes in productivity and the general inflation rates may be a more efficient intervention.
\end{abstract}

\section{INTRODUCTION}

That Pakistan has been able to divest 86 manufacturing units, two banks, one development financial institution, one thermal power unit, 12 percent share of Pakistan Telecommunication, and 10 percent shares of Pakistan International Airlines over the last five years and its intention to divest the remaining manufacturing enterprises, all banks and DFIs, thermal power stations of WAPDA, and tele-communications shows her commitment to privatisation. While divestiture has gone ahead at a rapid pace, its intended impact on fiscal deficit and levels of efficiency may have not been realised. As a matter of fact, Naqvi and Kemal (1991) had pointed out that just changes in the locus of ownership may not improve the levels of efficiency. Even more importantly Kemal (1993) and Naqvi and Kemal (1994, 1997) found a decline in output and an increase in the prices of products relating to the privatised industries. The evidence from other countries on impact of privatisation on efficiency is not conclusive. For example, Caves and Christensen (1980); CIDA (1987); Selim (1988); Yotopolous (1989); Foreman-Peck (1989); Edgren (1990); Vuylsteke (1989); Nankani (1989); Candoy-Sekse (1989); Kikeri, Nellis and Shirley (1992); Sen (1992) and Baumol (1996). The general conclusion emerging from these studies is that it is not the locus of ownership but the quality of management and market structure which determines the performance of a firm.

That privatisation would lead to higher levels of efficiency is based on the

A. R. Kemal is Chief Economist of the Planning Commission, Government of Pakistan, Islamabad. 
premise that survival of the private firms depends on cost minimisation while public sector firms may not be motivated enough to reduce their cost of production. That assumes perfectly competitive markets in which private sector is to operate and which are non-existent in Pakistan. Moreover, if government intends to privatise even those industries/activities where scale economies are rather significant then there is an imminent danger that private monopolies may substitute the public monopolies. The need is, therefore, obvious to analyse Pakistan's privatisation experience with respect to growth in output, efficiency and prices and to examine the possibilities of regulating the industries so that a competitive solution in the private sector monopolies is ensured.

The plan of the paper is as follows. After this introductory section, the impact of privatisation on efficiency in Pakistan is examined in Section II. The possibility that privatised firms may be inefficient at equilibrium levels unless regulated and an efficient regulation framework is examined in Section III. Main conclusions are summarised in Section IV.

\section{THE IMPACT OF PRIVATISATION ON EFFICIENCY}

The impact of privatisation on levels of efficiency has been examined in the following through its impact on the growth rate of output, change in prices, and return on equity/fixed assets.

\section{Growth of Output}

With a view to examining the impact of privatisation on changes in the growth of output, analysis of variance was carried out to test if the growth rate of output in the privatised industrial sector in pre-privatisation and post privatisation period were different. Pakistani data do not allow us to reject the null hypothesis that there is no difference in the growth rate of output. ${ }^{1}$ It suggests that privatisation has left the efficiency of the manufacturing industries unchanged.

It is quite well-known that the monopolist would try to maximise its profits by restricting the output and increasing the prices unless through public intervention he is not allowed to exploit the monopolistic power. Accordingly, privatisation may even lead to lower levels of efficiency. Whether privatisation has led to an increase or a decline in the growth rate of privatised industries, growth rate of output in the post privatised period of the industrial sectors in which at least some industrial units have been privatised is regressed against the growth rate of the same industry prior to privatisation, market concentration and/or level of protection. Accordingly the following relationship has been estimated.

$$
P R I=a+b P u b+c \text { Con }+d P R O
$$

${ }^{1}$ The $F$-ratio turns out to be only 1.33 . 
where:
$P R I=$ Growth rate of production after privatisation.
$P U B=$ Growth rate of production prior to privatisation.
$C O N=$ Concentration ratio.
$P R O=$ Protection provided to the industry.

Since privatisation is expected to increase the growth rate, $a$ priori, $b>1$. Since concentration in the sellers market allows an industry to exploit the monopoly power, $c<0$. While there are a number of concentration measures such as four firm concentration, Heifindhal Index etc., but they are not available after 1967-68 for Pakistan and as such we have been constrained to use number of firms as a measure of concentration. Protection tends to promote economic activity and as such growth rate of protected industries may be higher. However, if protection remains constant over time, then it may act as another measure of concentration. Therefore, $d<0$. Effective protection rate and nominal protection rates have been alternately used in the specification to compute the impact of protection on the growth rates. ${ }^{2}$ The results obtained are as follows:

$$
\begin{aligned}
& P R I=1.62+0.78 P U B-0.02 C O N-0.07 E P R+0.06 N P R \\
& \begin{array}{llll}
(0.29) & (2.08) \quad(0.13) \quad(1.27) \quad(0.79)
\end{array} \\
& R^{2}=0.47 \quad D W=1.45 \\
& P R I=1.99+0.77 P U B+0.007 \text { CON }-0.046 E P R \\
& \text { (0.31) (2.12) (0.04) (-1.018) } \\
& R^{2}=0.42 \quad D W=1.66 \\
& P R I=3.24+0.57 P U B+0.102 C O N+0.0067 N P R \\
& \begin{array}{lll}
(.76) \quad(1.63) \quad(0.64) \quad(0.109)
\end{array} \\
& R^{2}=0.30 \quad D W=2.41 \\
& P R I=-2.88+0.59 P U B+0.99 C O N \\
& \text { (1.99) (1.86) (0.68) } \\
& R^{2}=0.33 \quad D W=1.37
\end{aligned}
$$

Quite surprisingly these results suggest a significant decline in the growth rate after privatisation. However, the decline in this period cannot be ascribed to just privatisation as during this period a general slackness in the economic activity has been observed. The growth of GDP and particularly that of the industrial sector has fallen rather significantly. Nevertheless, to some extent decline in the growth rate of overall manufacturing sector may have been due to the fact that there has been a decline due to privatisation of manufacturing industries. Moreover, as we see in the 
following the decline in output has accompanied with an increase in prices suggesting that privatisation may have led to a decision of the monopolist to reduce the output.

The sign of concentration is correct, but the coefficient is insignificant. However, this may be due to the fact that number of firms show very slight variation across these industries. Same is true of the protection coefficient.

\section{Changes in Prices}

Probably from consumers' stand point, the benefit of privatisation must be reflected in reduction of real prices of the products of the privatised firms. The fall in real prices would also indicate an increase in the levels of efficiency. While the prices of the products of privatised firms increased at a rate of 6.1 percent in the preprivatisation period as compared to the general inflation rate of 9.3 percent, the prices in the post-privatisation period increased by 16.3 percent as compared to the general inflation rate of 10.5 percent. This does suggest that producers may have been able to exploit their monopoly power.

\section{Changes in Profitability}

Two what extent the net profitability of the privatised firms have increased, changes in return on equity and return on fixed assets after privatisation has been regressed against returns in pre-privatisation period.

$$
\begin{aligned}
R O E_{P R}= & 17.53+0.94 R O E_{P u} \\
& (1.11) \quad(.033) \\
& R^{2}=0.17 \quad D W=1.53 \\
F A_{P R}= & 8.85-0.111 F A_{P u} \\
& (0.44) \quad(0.64) \\
& R^{2}=0.06 \quad D W=1.53
\end{aligned}
$$

Where ROE is return on equity

FA is return on fixed assets

subscripts $P R$ and $P u$ refer to after and before privatisation.

The coefficient is statistically insignificant implying no change in the return on equity and fixed assets as a result of privatisation.

\section{MONOPOLISTIC MARKET STRUCTURE AND REGULATION}

Let us consider an industry with constant returns to scale and examine its behaviour under perfectly competitive and monopolistic market structures. In a competitive market structure, prices would equal the marginal cost and in a monopolistic situation, prices would exceed marginal cost. Obviously, if private 
sector operates in a monopolistic situation, ${ }^{3}$ prices would be higher, consumer surplus would fall and the producer would not operate at the minimum average cost. Accordingly, where scale economies are significant, privatisation may lead to lower level of productivity; even if the cost curve of private producers lie below the cost curve of the public sector producer at each level of production, privatisation may not lead to higher levels of productivity as shown below.

Let $A_{\mathrm{g}}$ and $\mathrm{AC}_{\mathrm{p}}$ refer to average cost curves of public and private sector and $\mathrm{MC}_{\mathrm{g}}$ and $\mathrm{MC}_{\mathrm{p}}$ refer to marginal cost curves of public and private sectors (See Figure 1). They face the same demand curve (Dp) and marginal revenue curve (MR). The private producer is in equilibrium at point $A$, and the output levels is $O Q$, and average and marginal costs at the equilibrium point are $O A$ and $O B$. If public sector firm operates at the same level of output, i.e. $O Q$, the average and marginal cost of public firm are $\mathrm{OA}$, and $\mathrm{OB}$ respectively, and both exceed the respective costs in the private sector. However, public sector may not restrict output to $O Q$, and expand output to $\mathrm{OQ}_{1}$, if marginal cost pricing rule is adopted or $O Q_{n}$ if average cost pricing rule is adopted. At both the levels of output, marginal cost of the public sector firm falls short of the marginal cost at the equilibrium point of the private producer. It is, therefore, obvious that privatisation of natural monopoly may result in lower levels of productivity.

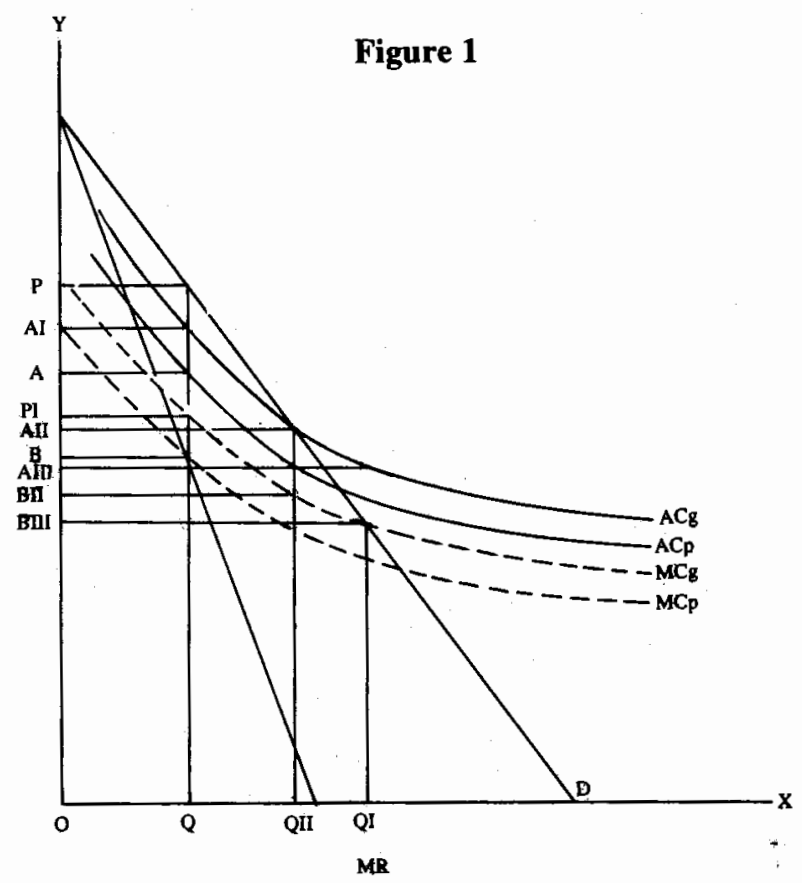

${ }^{3}$ In an industry exhibiting constant returns to scale, the size of the firm is indeterminate. It is consistent with both the competitive and the monopolistic market structures. 
While trade policy may be employed to curb monopolistic exploitation of the producers, such a possibility does not exist in case of non-traded activity. No doubt, monopolies can be regulated but close regulation of investment and other decision of the firms may leave very little room for the producers of the privatised firms to improve their levels of efficiency. Tight regulation may even leave the private producers worse off compared to the managers of a public enterprise. Unless, there is an efficient regulation framework, as has been discussed by Baumol (1996), regulation may be detrimental to growth of productivity.

Baumol lists six regulation mechanisms usually employed to regulate privatised firms, and he advises against their use. Firstly, because of the fear of monopoly power, the regulators try to inject more competition by mere introduction of additional firms into market which is no guarantee for effective competition, especially when the scale economies are significant. Second, cross subsidies are generally maintained and they drive far out of line the prices which economic efficiency requires. Third, regulators sometimes impose exclusive territories for different competitors as has been done in British Telecom where the territories has been spelt out which tend to increase cost and lower the level of efficiency. Fourth, the regulated firms face the danger of inconsistency in the regulators' policy which may not be foreseen by the management. Fifth, regulation may cause delays and the producers may not be able to quickly take the decisions in accordance with the market conditions. Sixth the privatised firms are regulated through accounting conventions such as fully distributed cost which generally are arbitrary. Since this boils down generally to cost plus formula for prices, it eliminates any incentives for reducing the cost. As is quite well-known economic regulation is to facilitate and encourage effective competition where it is feasible and provide an effective substitute for competition where it is not possible. The regulator has to supply a substitute for enforcing effective competition.

Where the scale economies are significant, multiplicity of firms will probably neither be feasible nor desirable and marginal costs pricing will be incompatible with solvency of the firms. Accordingly, the concept of "perfect contestability, defined as the state of a market in which there is totally costless and an unimpeded freedom of entry and exist must serve the model.” Accordingly, Baumol outlines the following seven rules of economic regulation.

1. Where there is evidence of competition, regulators should refrain from intervention.

2. Where completion can be stimulated, it must be done.

3. The regulators should make sure that prices in the long run do not exceed the levels which in a perfectly competitive market would make entry profitable.

4. Prices should not be permitted to go below the level which is viable for any substantial period in a competitive or contestable market, i.e. prices should 
not fall short of the marginal cost of any product or the per unit incremental cost of the entire output of any homogenous product.

5. Because in a contestable market one may encounter prices close to the stand-alone cost ceiling or the marginal-average cost floor, the firm should be left free to adopt any price within these limits.

6. Price caps should substitute for fixed ceilings on total earnings or for a fixed ceiling on rate of return on investment.

7. When inputs are supplied by a regulated firm, both to itself as a component of one of its final product, and to a competitor producer, the regulated firms should charge the rival the same price for that input that the former implicitly charges to itself.

\section{CONCLUDING REMARKS}

While divestiture policy of Pakistan has been quite successful in the sense that 86 manufacturing units, two commercial banks, and one development financial institution, ten percent of the shares of PIA, and about 12.0 percent of telecom shares etc., have already been divested, it has not helped in raising the level of efficiency. Privatisation would increase the efficiency of the privatised units only if it took place in a competitive market structure. The evidence on growth of output and change in prices in the activities so far privatised show that the producers have been able to exercise their monopoly power. Growth rates of output may have fallen and prices have increased. Rate of return on equity and fixed assets seem to have remained constant. These results are not very encouraging for privatisation; if monopolistic practices have prevailed even in the industries which produce tradable goods, the privatisation of non-traded activities would definitely result into monopolistic exploitation.

Regulation of industry to force a competitive solution on the monopolist is generally taken as an optimum solution alongwith privatisation. However, if regulation implies that it creates uncertainty for the producers and the producers have even lower flexibility in decision-making even as compared to public sector enterprises, it may be counter productive.

Since perfect competition model may result into solvency problems, it needs to be substituted with perfect contestability model which allows the firms to make sufficient profits and leave it quite free to take decisions. Probably price caps alongwith productivity and general inflation rate can be categorised as efficient intervention.

\section{REFERENCES}

Baumol, William J. (1996) Rules for Beneficial Privatisation: Practical Implications of Economics Analysis. Islamic Economic Studies 3:2 1-34. 
Candoy-Sekse Rebecca (1989) Techniques of Privatisation of State Owned Enterprises, Inventory of Country Experience and Reference. Washington, D. C.: The World Bank. (Technical Paper No. 90.)

Canadian International Development Agency (1987) A Study of Divestment of Industries in Bangladesh. 1: Dhaka: CIDA.

Caves, D. W., and Christensen (1980) The Relative Efficiency of Public and Private Firms in a Competitive Environment: The Case of Canadian Railroads. Journal of Political Economy 88:5 958-976.

Edgren, Gus (1990) Privatisation, Efficiency and Employment. Geneva: ILO, (Discussion Paper.)

Foreman-Peck, James (1989) Ownership, Competition and Productivity Growth: The Impact of Liberalisation and Privatisation on British Telecom. Warwick. (Warwick Economic Research Paper No. 338.)

Kemal, A. R. (1993) Retrenchment Policies and Labour Shedding in Pakistan. ILO: Genera. (Occasional Paper 17.)

Kikeri, Sunita, John Nellis and Mary Shirley (1992) Privatisation: The Lessons of Experience. Washington, D. C.: The World Bank.

Naqvi, Syed Nawab Haider, and A. R. Kemal (1991) The Privatisation Experience of Public Industrial Enterprises in Pakistan. The Pakistan Development Review 30:1 105-144.

Naqvi, Syed Nawab Haider, and A. R. Kemal (1994) Structural Adjustment, Privatisation and Employment in Pakistan. In Rizwanul Islam Social Dimensions of Economic Reforms in Asia. New Delhi: ILO, SAAT.

Naqvi, Syed Nawab Haider, and A. R. Kemal (1997) Privatisation, Efficiency, and Employment in Pakistan. In Tony Bennet (ed) Privatisation-How it Works. Routledge, London.

Nankani, Helen (1989) Techniques of Privatisation of State-owned EnterprisesSelected Country Studies. Washington, D. C.: The World Bank. (Technical Paper 89.)

Selim, R. (1988) Public and Private Enterprises in Bangladesh: A Case Study of the Jute Manufacturing and Textile Mills. (Unpublished M. S. Thesis submitted to the Postgraduate School of Studies in Planning, University of Bradford), England.

Sen, Binayak (1992) Privatisation in Bangladesh: Process Dynamics and Implications. In V. Kaneslingam Privatisation: Trends and Experiences in South Asia. Paper presented at an International Seminar organised by CSCD, Colombo, Sri Lanka.

Yotopolous, Pan A. (1989) The (Rip) Tide of Privatisation: Lessons from Chile. World Development 17:5 683-702.

Vuylsteke, Charles (1989) Technique of Privatisation of State owned EnterprisesMethods and Implementation. Washington, D. C.: The World Bank. (Technical Paper No. 88.) 